THE GREATER INDIA EXPERIMENT 
SOUTH ASIA IN MOTION

EDITOR

Thomas Blom Hansen

EDITORIAL BOARD

Sanjib Baruah

Anne Blackburn

Satish Deshpande

Faisal Derji

Christophe Jaffrelot

Naveeda Khan

Stacey Leigh Pigg

Mrinalini Sinha

Ravi Vasudevan 


\section{THE GREATER}

\section{INDIA EXPERIMENT}

Hindutva and the Northeast 


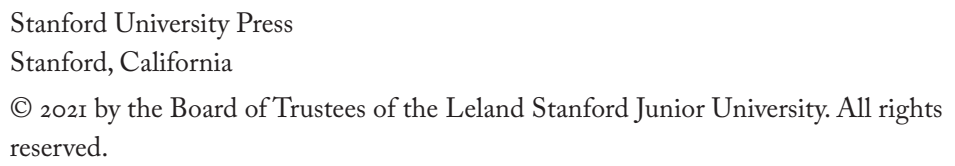

No part of this book may be reproduced or transmitted in any form or by any means, electronic or mechanical, including photocopying and recording, or in any information storage or retrieval system without the prior written permission of Stanford University Press.

Printed in the United States of America on acid-free, archival-quality paper

Library of Congress Cataloging-in-Publication Data

Names: Longkumer, Arkotong, author.

Title: The greater India experiment : Hindutva and the northeast / Arkotong

Longkumer.

Other titles: South Asia in motion.

Description: Stanford, California : Stanford University Press, 202I. | Series: South Asia in motion | Includes bibliographical references and index.

Identifiers: LCCN 2020019950 (print) | LCCN 202001995I (ebook) |

ISBN 978I50361346I (cloth) | ISBN 978I5036I4222 (paperback) |

ISBN 97815036r4239 (epub)

Subjects: LCSH: Sangh Parivar. | Hindutva-India, Northeastern. | Hinduism and politics-India, Northeastern. | Nationalism-India, Northeastern. | HinduismIndia, Northeastern-Relations. | India, Northeastern-Politics and government. Classification: LCC DS482.8 .L66 202I (print) | LCC DS482.8 (ebook) |

$\mathrm{DDC}_{320.55-\mathrm{dc} 23}$

LC record available at https://lccn.loc.gov/2020019950

LC ebook record available at https://lccn.loc.gov/202001995I

Cover photo: Mural commissioned for the Tribal Heritage Museum, Rajiv Gandhi University, removed and relocated to the balcony of the Museum due to criticism that it resembled a Hindu deity. Arunachal Institute of Tribal Studies and the Tribal Heritage Museum.

Typeset by Westchester Publishing Services in 10.75/15 Adobe Caslon 